15 in the historic Caucus Room of the Russell Senate Office Building, site of the Teapot-Dome, Watergate, Iran-Contra, and Clarence Thomas nomination hearings.

In addition to approximately 200 current and former Fellows and friends of the program, Senator Richard Lugar (R-IN), Representative Steve Horn (R-CA), and Thomas Foley, former speaker of the House of Representatives, all of whom are members of the CFP Advisory Committee, and Donna Shalala, Secretary of Health and Human Services were in attendence.

The reception was funded through the generosity of MCI Communications which, in 1991, presented the Congressional Fellowship Program with an endowment of $\$ 5$ million.

\section{Dan Palazollo: A Day in the Life of an APSA Congressional Fellow}

In the Cannon House Office Building, Daniel J. Palazzolo leans back in his chair, props both feet on his desk, and surveys his schedule.

"I'm juggling a half-dozen issues, but this should be a pretty uneventful day," says Mr. Palazzolo, an associate professor of political science at the University of Richmond. He is on a year's leave, working with Representative Robert L. Ehrlich, Jr., a Maryland Republican, on a fellowship sponsored by the American Political Science Association.

But as he tucks his schedule back into his shirt pocket, his "catch-up" day is blown apart. Earlier that morning, on a radio talk show, he is told, Mr. Ehrlich's predecessor, Helen D. Bentley, criticized a bill to reform U.S. patent law, which the Congressman supports. The bill would, among other things, put the federal Patent and Trademark Office in private hands, hurting independent inventors and small businesses and giving foreign inventors an edge over Americans, Ms. Bentley said.

Within 15 minutes of her comments, constituents concerned about the bill's ramifications have jammed the phones and facsimile machines in Mr. Ehrlich's offices on the Hill and back in his district.

Steven Kreseki, the Congressman's legislative director, huddles with $\mathrm{Mr}$.
Index of APSA Reports in PS, September 1996-June 1997

Article

Issue

Page

American Political Science Review

Computerized APSR: Research at Your Fingertips

Past Issues of $A P S R$ Available On-Line

Report of the Managing Editor of the American Political Science Review, 1995-96

Annual Meeting 1996

San Francisco Breaks Annual Meeting Record

Awards

1996 Teaching Awards Recipients

APSA Awards Presented at 1996 Annual Meeting

Committees

APSA Committees

Congressional Fellowship Program

CFP Announces 1996-97 Competition Winners

Report on the Congressional Fellowship Program, 1995-96 and 1996-97

Council

APSA Council Minutes, April 1996

APSA Council Minutes, August 1996

Dissertations

Additional Dissertation Listing

Choosing a Dissertation Topic

Executive Director

Report of the Executive Director

Internet Report

APSA On-Line

Governing Rules

APSA Changes Dues Categories and Increases Some Dues

Annual Meeting Business Rules

National, Regional, and State Association News

Listing of National Political Science Associations

Listing of Regional and State Political Science Associations

Organized Sections

Section News

Update on Organized Sections

Section News

Presidents and Officers

APSA Treasurer's Report

Association Officers and Council Members Nominated for 1997-98

New APSA Officers Elected

Profession

Forum: Tenure Trouble

Multimedia Sources for Instruction in Political Science

Political Science Chairs Recommend Strategies to Counter Decreases in Undergraduate Enrollments

Political Science Departments Report Declines in Enrollments and Majors in Recent Years

Trends in the Profession

Professional Development

Annual Meeting Short Courses Promote Professional Development PS Reports

Index of APSA Reports in PS

PS Index of Authored Articles

Publications

Publications List

Publications List

Publications List

Publications List

Research Support

Association Awards 1996 Research Grants

Women and Minorities

APSA Announces 1997-98 Minority Student Graduate Fellows

The Teacher: Mainstreaming Gender Research in the Classroom

NSF Funds Ralph Bunche Summer Institute

Ralph Bunche Summer Institute Participants Named

University of Virginia and Others Support the 1996 Ralph Bunche Summer Institute
March 1997

September 1996

December 1996

97

562 758

December 1996

737

December 1996

December 1996

683

839

March 1997

133

September 1996

559

March 1997

138

September 1996

December 1996

618

March 1997

836

June 1997

106

213

September 1996

549

March 1997

September 1996

June 1997

June 1997

March 1997

December 1996

December 1996

June 1997

December 1996

June 1997

234

December 1996

770

March 1997

\section{0}

March 1997

December 1996

September 1996

March 1997

December 1996

September 1996

564

March 1997

September 1996

624

December 1996

March 1997

June 1997

863

142

275

September 1996

557

March 1997

100

June 1997

194

June 1997

99

September 1996
March 1997 